\title{
Research on Habermas's Thought on the Relationship Between Right and Power
}

\author{
Li Bo \\ The School of Marxism, Tiangong University, Tianjin, P. R. China \\ Email address: \\ libo2823@126.com \\ To cite this article: \\ Li Bo. Research on Habermas's Thought on the Relationship Between Right and Power. Humanities and Social Sciences. \\ Vol. 9, No. 1, 2021, pp. 7-13. doi: 10.11648/j.hss.20210901.12
}

Received: December 26, 2020; Accepted: January 18, 2021; Published: January 25, 2021

\begin{abstract}
How to accurately grasp the relationship between right and power is one of the core propositions of political philosophy, and is also a theoretical issue that Habermas has always paid great attention to. By studying Habermas's thought of the relationship between right and power, we can not only deeply understand the basic concepts of his political philosophy, but also explore the way of thinking to safeguard civil rights and balance political power. Compared with traditional political philosophy, it is not difficult to find that Habermas neither advocates the separation of right and power as liberals, nor advocates the absolute integration of the two as republicans. In his view, the right to be the outcome of citizens' spontaneous interaction must rely on coercive political power to enter into force. At the same time, political power can only obtain the legitimacy of existence in accordance with the principle of "people's sovereignty" of the discourse theory, and this legitimacy foundation is precisely reflected in the right system of communication cycle. In short, right and power restrict each other and depend on each other, and they present an isomorphic relationship with moderate tension. Obviously, this view is a historical advance of political philosophy and has great theoretical and practical value.
\end{abstract}

Keywords: Habermas, Right, Power, Liberalism, Republicanism

\section{Introduction}

As a philosopher with a strong sense of social responsibility, Habermas has brought the issue of the relationship between right and power closely related to social and political practice into his theoretical vision since the beginning of his academic career. As opposed to the views of traditional liberals or republicans, Habermas thinks that right is neither a pure individual "human right" nor the "popular sovereignty" in the category of absolute collectivism, but a social relationship based on the discourse theory that can stipulate the mutual obligations and responsibilities between different subjects. On this basis, Habermas further points out that there is neither a huge gap between right and power, nor an unbounded integration between them and they are reflected in an isomorphism relationship that is both interdependent and mutually restrictive. Therefore, on the basis of summarizing the lessons learned from past theories, Habermas transcends the one-dimensional thinking mode of liberalism and republicanism, completes the reconstruction of the relationship between right and power, and creates a new situation for the development of political philosophy.

In a word, the relationship between right and power is one of the core issues of Habermas's political philosophy. Through the research on this issue in this paper, we can deeply understand the formation basis, evolution path and thinking characteristics of Habermas's political philosophy theory. Based on this research, we can analyze the relationship between various components of Habermas's grand philosophical system from one side, so as to deepen the overall cognition of his thought.

\section{The Understanding of the Relationship Between Right and Power in Traditional Political Philosophy}

What is the relationship between right and power? It is not a new problem. Before Habermas, the two main schools of political philosophy --liberalism and republicanism-- explored this issue in depth and their achievements greatly promoted the development of political philosophy. However, due to the 
narrowness of their views, both sides have some defects in their understanding of this issue.

In general, liberalism has always adhered to the basic concept of "the separation of the state and civil society" and "emphasizes the independent existence of individuals, and believes that such independence takes precedence over any social organization and political order" [1]. Therefore, in its context, the connotation of "rights" can only be the rights of individuals in civil society, namely "human rights". Accordingly, power, as a political mandatory force carried by the state (Since modern times, with the formation of the nation-state and the establishment of the concept of national sovereignty, the autonomous communities of traditional societies have been all integrated under the state power. Therefore, in the context of the vast majority of modern political philosophers, national institutions are the direct carrier of political power, and "political power" and "state power" are the same in connotation - the author's note), may potentially threaten the smooth realization of the individual rights of citizens. Therefore, there is always a tension between right and power.

Based on the above considerations, liberals have drawn clear operating boundaries for power, trying to limit power once and for all within a framework conducive to the realization of civil rights. However, because such negative precautions establish too direct a connection between right and power, right has to be unconditionally subject to the manipulation of power in the name of "protection". In this way, citizens' autonomous political participation will be gradually marginalized, and their "right of freedom" will also be seriously violated by the "organized state authority".

To be specific, when the role of the state is strictly limited to the "night watchman" of social and economic life, on the one hand, people take it for granted that the political state and civil society will henceforth perform their respective duties and do not interfere with each other, so they gradually relax the necessary vigilance against the former. On the other hand, the chaos of anarchy fills people with fear and makes them naturally dependent on the authoritarian system of the political state. In this way, as an institutional organization, the country can occupy the core position in the political field, and its ability to regulate social life can easily be highly affirmed by people. The problem, however, is that the few political elites who directly manage the state's institutions are too limited in their vision to represent the interests of all parties fairly, and they often give empty talk. As a result, it is common that in the elitist political model, "the law gives the appearance of legitimacy to the illegal power" [2] (p49), and the basic rights of citizens lose the last barrier.

Republicanism, in contrast to liberalism, never believes that there exists an insurmountable gap between the political state and civil society, and highlights that the whole society is a unified political community. In the perspective of republicanism, individual rights do not have priority, and the connotation of "rights" can only lie in the freedom of all citizens to pursue common interests, namely "popular sovereignty". Since the political state and the social community are mutually exterior and interior, the political power carried by the former is also naturally responsible for safeguarding the common interests of the citizens, and the masses can use it freely according to their own will. Therefore, in the ideological system of republicanism, power is actually controlled or even eliminated by collectivist right. Taking this as an opportunity, the two have achieved a high degree of integration.

It should be admitted that republicanism overcome the disadvantages that liberalism gives undue prominence to individual rights to some extent with the prominence of public autonomy. But, it is a pity that this theory is also unable to fundamentally improve the human political practice. Imagine that if political power were severely compressed, the state would degenerate into an instrument of civil will, and direct public participation would grow into a decisive force in politics. Although republicans have to admit the legitimacy of representative democracy due to the complexity of social structure, for them, "the representatives participating in political talks are not the representatives of different interest groups in civil society, but the representatives of all citizens" [3]. These representatives do not and cannot have independent value judgments. They must know at all times and in all places what the people who entrust them with their decisions are thinking, so that the electorate always exerts its influence in a subtle way. In addition, the purpose of the delegates' discourse activities is not to bargain for their own interests, but to pursue the collective interests of all citizens and achieve the highest level of "common good". The problem is that "according to group psychology, voters... are often dominated by their own emotions and are easily influenced by external forces" [4]. As a result, they often destroy individual liberty in the name of the public and implement the so-called "tyranny of the majority". Thus it can be seen that "general will" advocated by republicanism is not reliable in fact. On the contrary, it is the popularity of this concept that has caused the repeated occurrence of democratic chaos in history, which has caused human society to pay a heavy price for development.

\section{Habermas's Thought on the Relationship Between Right and Power}

Different from the traditional one-dimensional political philosophy theory, Habermas believes that right and power are neither diametrically opposed nor absolutely integrated, but a kind of isomorphism relation that depends on and restricts each other. Only with a clear understanding of this concept, people can find the best balance point in the game between civil rights and political power, and then improve the management system of contemporary society. Specifically, the main contents of Habermas's thought on the relationship between right and power are as follows:

\subsection{Right Realizes Itself Through Power}

As noted earlier, liberalism is based on the individualism of 
rights (i.e., "human rights"), highlighting the opposition between power and right. In contrast, republicanism focuses on the collectivism of rights (i.e., "popular sovereignty"), emphasizing the inherent consistency between right and power. Thus it can be seen that the priority of private autonomy or public autonomy in the perspective of rights fundamentally determines the theoretical attitude of liberalism and republicanism. Habermas is clearly aware of this point, so his reconstruction of the relationship between right and power starts from the construction of a new concept of rights that takes both public and private into account.

According to Habermas, private autonomy and collective autonomy are not isolated from each other, but intrinsically intersected. This is because that any kind of private autonomy must be authorized by the collective to be effective, and participation in collective affairs is also an option within the scope of citizens' private autonomy. In his opinion, the reasonable concept of rights not only should meet the requirements of the "moral-centered theory" to allow the different interests of any individual to be considered from the same perspective, but also can achieve the related goals of "ethical axiology" to ensure that the members of the political community reach an agreement on their common interests. For this reason, Habermas decisively abandoned the either-or mode of thinking of traditional political philosophy, and began to unify individual choice and collective will by a comprehensive and universal democratic discourse, and then reshaped the concept of rights.

Generally speaking, Habermas opposes the natural endowment of rights or the state empowerment of rights, but advocates the mutual empowerment of rights [5]. In his view, rights are neither things that are merely used for possession or distribution in the eyes of liberals, nor a set of value standards that are highly suspended in social life advocated by republicans, but "a relationship, a social convention... which includes both the qualification requirements for others and various obligations to them" [2] (p110-111). It is in the right structure of above "inter-subjectivity" that "the individual and the community, the individualization and socialization, the autonomy of the individual and the consensus of the community are organically connected" [6]. Obviously, by integrating the relationship between "private autonomy" and "public autonomy", Habermas points out the homology between "human rights" and "popular sovereignty", establishes a new connotation of the concept of rights, thus greatly expanding the theoretical space of political philosophy. But Habermas also points out clearly that, although relying on the concept of rights in the sense of discourse theory, the premises for members of modern political community to participate in political life are finally clarified. The problem, however, is that this kind of achievement achieved by the spontaneous interaction of all citizens can only be regarded as a rational moral norm in nature, and it cannot be directly regarded as the norm of action by the members of the social community. This is because, in the modern society, rational morality is only a kind of knowledge in the final analysis, which, like all other knowledge systems, is manifested in the pure metaphysical level of "culture", and its implementation completely depends on the level of human conscience. Therefore, if the concept of rights, as a universal ideal moral norm, attempts to have a direct impact on the real society, it can only depend on whether the subject personality of all citizens participating in the formulation is high enough. However, it is undoubtedly difficult to rationally regulate the nobleness of each individual's personality, which means that the right recognized by all citizens cannot "only rely on the recognition and cooperative protection of fellow citizens" [7] to achieve its theoretical goals, and there is no necessary connection between its knowledge and actions.

In view of this, in order to ensure the unity of knowledge and practice and the implementation of rights, Habermas stresses the need to introduce a legal system backed by political power to concretely express civil rights. There are three reasons, which are embodied on the level of mental cognition, in the terms of implementation efficiency and in the aspect of system guarantee.

Firstly, as a universally discoursed rational morality, civil rights "are unable to make a list of obligations, let alone a normative rank order... Moreover, the freedom of association which they (namely citizens participating in democratic discourse - the author's note) enjoy in moral discourse only leads to fallible insight in the disputes of interpretations" [2] (p140). That is to say, the pure claims of rights rely too much on the thinking and judgment of citizens themselves, which leads to a high degree of cognitive divergence. Thus, it is difficult that the claims are implemented in the process of social management. Legal system, in contrast, can reduce the cognitive burden of citizens through the rigorous legislative process of the Parliament, "the precise description rules of jurisprudence and the professional work of systematically sentencing" under the maintenance of a state apparatus running at high speed, and clearly define the subject's norms of action with factual authority and indicate the direction for the citizens' social activities.

Secondly, since the subject of claim of rights is all the citizens participating in the democratic discourse process, whose attribution and division of responsibility are often very unclear, and even have strong randomness, so it is impossible to build an efficient and comprehensive action network based on the subject in the specific political practice process. In contrast, the legal system, relying on the bureaucratic state authority, has created a perfect and detailed attribution system of responsibility by means of organization construction and authority management and so on to ensure that any specific claim of rights of citizens will be timely achieved by the corresponding subject of responsibility. In this regard, as pointed out by Habermas, "state establishes its ability to organize and self-organize so as to maintain the common life organized by law in both external and internal aspects" [2] (p166), thus ensuring that the moral content contained in the claims can be extended to every member of society through legal regulation.

Thirdly, as mentioned above, as a highly abstract system of rational moral norms, the biggest limitation of civil rights lies 
in its lack of strong guarantee for the realization of self-requirements. Therefore, civil rights can only place its hopes on the individual's own will strength and produce very limited practical effects on social life. In contrast, the law can get rid of its dependence on the motive and attitude of the behavior subjects through the operation mechanism backed by the state power and punish all kinds of illegal acts by the state apparatuses such as the military, the police, the courts, the prisons and so on, so as to ensure the factuality and definiteness of the behavior subjects to fulfill the requirements of the norms. Thus it can be seen that the code of conduct that "ought to be observed" is not necessarily "bound to be observed" by all citizens. In contemporary society, the basic rights demanded by citizens, such as freedom, equality, fairness and justice and so on, can be truly effective and implemented only when the law is used as an intermediary to obtain the institutionalized guarantee of "organizations (namely political state - the author's note) capable of making binding decisions on the collective" [2] (p165).

In a word, Habermas believes that only by relying on the supplement and support of the institutionalized legal system based on the national political power can the civil rights system with strong moral color complete the fundamental transformation from "oughtness" to "isness" and become an effective activity norm to be observed by members of the social community. In other words, with the law as the intermediary, state power provides the necessary cultural, organizational and social conditions for citizens to satisfy their private freedom and universal political participation. Without the strong support of the state power, the civil rights system formed on the basis of democratic discourse can only be manifested as a metaphysical knowledge system rather than an action system of social practice, which can never be understood and recognized as an institutional action rules that must be observed. Therefore, the existence of political power is actually required in advance by civil rights, and the scale and weight of the former in fact determine the degree of realization of the latter.

\subsection{The Legitimate Existence of Power Depends on Right}

Although political power is preset by civil rights, it does not mean that its formation and development are natural and reasonable. In Habermas's view, if power attempts to gain legitimacy for its own existence and implementation, it must meet the relevant requirements of the principle of "popular sovereignty". In briefly, the content of "popular sovereignty" is simply that "all political power comes from citizens" communicative power" [2] (p207). Therefore, the core step of proving the legitimacy of power lies in the interpretation of "communicative power".

Trace back to the source, the concept of "communicative power" was borrowed by Habermas from Hannah Arendt's theoretical system. According to Arendt's point of view, the subjective activities carried out by human beings can be divided into three types: Labour, Work and Action according to the degree of immortality of the consequences obtained.[8] "Labor" is based on the private domain, and its purpose is to meet the most basic physiological needs of human beings. "Work" is a creative activity carried out by human beings in the social field and its existence enables human civilization to successfully find its habitat in nature, forming an artificial world completely different from the nature world.[9] "Action" is a unique activity of human beings and it fundamentally reflects the difference between human beings and animals. In this activity, people get rid of the entanglement with the natural being or social creation, and carry on the direct communication with each other through the public domain. The inner strength shown in the process of dialogue and action, namely the "order of action oriented by understanding", directly constitutes the logical origin of the formation of communicative power. As Arendt repeatedly puts it, power "arises when people come together and 'act in concert' and disappears once they leave" [10].

Habermas greatly appreciates Arendt's practice of constructing a direct link between power and human interaction. However, as far as the generation mechanism of communicative power is concerned, Habermas does not believe that the foundation of communicative power lies entirely in the public domain. On the one hand, the open and pluralistic characteristics of the public domain make it very keenly recognize the latest political issues, and in the first time to respond to citizens' demands, but the characteristics also lead to its rheological state for a long time to difficultly form a stable political opinion and policy strategy, which is the biggest taboo in social management. On the other hand, not only ordinary people but also many representatives of interest groups are involved in the communication in the public domain, and interest groups with a large number of social resources tend to use various channels (such as mass media) to constantly enhance their influence on consumers, voters and parties [11], thus gradually realizing the penetration into the public domain. That is to say, although "the people are never corrupted, they are often deceived" [12], thus public opinion can be manipulated. Although such a situation is not likely to happen in a well-functioning public domain, we cannot ignore this risk and blindly equate public opinion with communicative power.

In a word, public domain is just a non-institutionalized communication network. Although public opinions formed in it can broadly reflect the will of citizens, the variability and controllability fundamentally determine that it is not suitable to exist as a direct communication power

In order to overcome the above limitations of the public domain, Habermas decided to introduce the parliamentary group into the generation mechanism of communicative power. There is no denying that, different from the activities in the public domain, the activities of the parliamentary group are restricted in many ways. Firstly, the communicative subjects are generally acted by professional politicians or professionals in various fields, and there are relatively few opportunities for the general public to participate in the parliamentary group. Secondly, the parliamentary group has definite boundaries in social space and historical time, so it cannot start a conversation anytime and anywhere. Thirdly, 
the parliamentary group does not have the ability to put the issues into reality, and can only rely on the post-processing and operation of the administration. But every coin has two sides. For the parliamentary group, it has its own unique advantages in spite of many restrictions. On the one hand, professional politicians and specialized talents can conduct democratic discourse in the relatively stable environment provided by it, which is undoubtedly conducive to the proposal of institutionalized political opinions and even the implementation of social management activities. On the other hand, relying directly on national administrative organs to implement their own issues can also effectively prevent the infiltration and manipulation of interest groups and avoid the emergence of false democracy.

It should be noted that Habermas once referred to the parliamentary group as a kind of "organized public domain". This is another interpretation of this concept in order to perfect his theoretical system, but it inadvertently leads many researchers to think that the public domain has a "two-layer structure" mistakenly. In fact, "organized public domain of the parliamentary complex" is only a relative concept in Habermas's context, and its character of "public" is more reflected in the public power possessed by the state institutions. Habermas always believes that the formation of institutionalized political opinions must take full account of the trend of public opinion, which shows that the status of parliamentary groups and the public domain are not exactly equal in his mind. The parliamentary group, therefore, is essentially just a frame of reference for Habermas to develop in his argument for the public domain, and the two are by no means comparable.

In conclusion, it is not difficult to see that in Habermas's ideological perspective, both the discovery environment of the public domain and the institutionalized mode of the parliamentary group play a huge role in the formation of the communicative power, and the foundation of the communicative power must be established in the process of mutual communication between the two political fields.

It is based on the above concepts that Habermas further explains the transformation process from communicative power to administrative power, which Arendt ignores. According to the understanding of Habermas, political power is actually made up of communicative power and administrative power together: "Politics as a whole is not confined to the practice of talking to one another in order to act autonomously in politics" and its concept has been extended to "the use of executive power in the process of competition for access to the political system" [2] (p184). Therefore, if the process is not explained, political power cannot prove its own legitimacy. Once this situation occurs, it may have two consequences. One is that communicative power directly replaces administrative power, but it is very easy for social and political life to fall into the undisciplined democratic chaos. The other is to compromise to the reality and recognize that the generation and implementation of political power are two separate processes, which cut off the connection between communicative power and administrative power, but this deviates from the original intention of Arendt's concept of "communicative power". In order to solve the above difficulties, Habermas suggests that "law should be regarded as the medium through which communicative power can be transformed into administrative power" [2] (p184). This is because the legislative process is intertwined with the formation process of communicative power, "the source of legal legitimacy lies in the communication between the participants in equal and reasonable discussion" [13], and there is a close connection between the Parliamentary group with legislative power and the government agencies with administrative power.

Therefore, as long as the formation process of public opinion, the election process of institutionalization and legislative decisions are combined, it is possible to ensure the smooth transformation of communicative power into administrative power through legislative activities, thereby establishing the legal basis of political power.

Habermas's discussion on the formation basis and operation procedure of "communicative power" can be shown in the following figure:

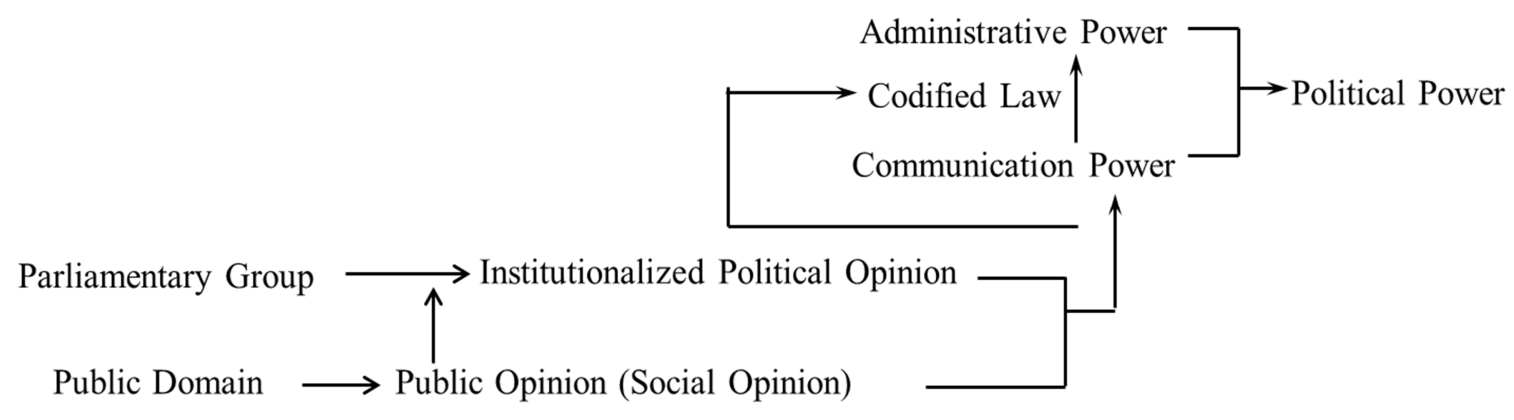

Figure 1. The Formation and Operation of "Communicative Power"

As is shown in the figure, in the dual-track political system designed by Habermas, the combination of the public domain and the parliamentary group leads to the final formation of communicative power, which is transformed by codified laws into administrative power with practical action ability. Then, the above two constitute political power together.
Through Habermas's analysis and transformation of "communicative power", we can easily see the special features of his principle of "popular sovereignty":

It does not promote the direct democracy of the visible congregations of the citizens of ancient Greece, nor does it glorify the parliamentary politics that prevail today. 
Fundamentally speaking, this concept is a principle of power legitimacy in the sense of discourse theory and its foundation lies in the communication cycle composed of social forums and parliamentary groups. Whether in the public domain or in the parliamentary group, the direct premise of achieving universal political communication lies in the equal right of political participation enjoyed by citizens. Thus it can be seen that the ultimate purpose of the new principle of popular sovereignty advocated by Habermas is to explain that only the rights system formed on the basis of general recognition is qualified to act as the source of political power legitimacy.

To sum up, in Habermas's view, the relationship between right and power is such an isomorphic relation: they are neither incompatible as fire and water, nor in perfect harmony, but always maintain a certain degree of tension. While restricting each other, they also serve as the basis of each other's existence.

\section{On the Evaluation of Habermas's Thought on the Relationship Between Right and Power}

Habermas's reconstruction of the relationship between right and power breaks the conflict of liberalism and republicanism, and provides a new value standpoint for democratic politics and a creative theoretical approach for the complete realization of human freedom and equality, which is also the source of his ideological charm.

As we all know, freedom and equality are the core values of human society. The two together constitute the basic demands of democratic politics. However, the freedom advocating individual emancipation and the equality emphasizing collective self-discipline are inevitably conflicted in the process of political practice. In order to solve this problem, both liberalism and republicanism have put forward their own political construction programs to give consideration to freedom and equality in social activities. However, due to the one-sidedness of their positions, their efforts failed to achieve ideal results.

According to the liberal point of view, although freedom and equality are not high or low in status, they are different in logic order. Freedom is the birthright of every citizen, but equality is not. Equality can be realized among citizens only if every citizen is guaranteed the greatest freedom. Therefore, liberals understand rights "entirely in accordance with the moral principles of rational natural law" [14], and highly advocate the concept of "human rights" which emphasizes individual priority, and on this basis, emphasize the diametrical opposition between political power and civil rights in an attempt to create the most ideal external environment for the realization of individual freedom. However, they did not expect that the unchecked expansion of individual freedom would ultimately result in many privileges of a very small number of people in economy, politics, culture, etc., while the freedom of most ordinary people would become an illusion. Under such circumstances, equality naturally become a river without headwaters, or a tree without roots. Although neoliberals later made some improvements to classical liberalism, enhanced the status of state power in the political system, and curbed the unreasonable expansion of privileged private freedom to some extent, they failed to fundamentally solve the above problems. More seriously, with the continuous expansion of political power, social power which was originally active in the economic field began to gradually merge with it, forming the so-called situation of "social nationalization and national socialization". In this way, it is very likely that the whole society falls into the historical process of re-feudalization, and the hope of realizing the freedom and equality of the masses will completely be lost, which inevitably led to " the masses' thorough doubt about the principles and forms of political organization of late capitalism" [15].

The republicans take the opposite path from the liberals. In their view, the equality of citizens is the greatest freedom that every citizen can enjoy. Hence, individual freedom is irrelevant, and the core of the concept of rights lies only in collective popular sovereignty. Accordingly, political power has become the vassal of civil rights, and its main task is to take coercive measures against those individuals who refuse to obey the collective will to force them to achieve absolute conformity with others. The purpose is not only to ensure the smooth achievement of collective goals, but also to help individuals achieve true freedom.

There is no doubt that republicanism's advocacy of equality is, to a certain extent, in line with the fundamental interests of the people. It can even be said that it is it that constitutes the ideological core of many revolutionary theories in modern times. But at the same time, we must realize that republicanism's extreme understanding of the relationship between equality and freedom also causes many problems. In theory, republicanism inevitably leads to such weird perceptions as "forced freedom". In social activities, political practice directed by it is completely deviated from the original idea. Specifically, the absolute equality between citizens has not been achieved by forcibly depriving the false freedoms of the minority. On the contrary, the "tyranny of the majority" created by similar moves is often followed by an authoritarian government to clean up the mess. Obviously, if it comes to that, the freedom and equality of citizens will be out of the question.

Combining the lessons of liberalism and republicanism, Habermas believes that there is no primary or secondary difference between freedom and equality, and neither side is the appendage of the other. If all of them attempt to be realized, people must find the best balance point between them, and Habermas's analysis of the relationship between right and power is the embodiment of this reflection fundamentally.

As mentioned above, Habermas breaks the long-standing separation between individual freedom and collective freedom with his unique inter-subjective thinking mode, and gives a new interpretation to the concept of rights. This is actually an internal integration of freedom and equality, so that they can 
confirm the necessity and legitimacy of each other's existence. However, pure internal regulation is obviously not enough to maintain a stable relationship between the two, so it is necessary to intervene from the outside through political power to prevent people from being biased in the exercise of their rights. Of course, such intervention cannot be unlimited. It must be done within the limits authorized by civil rights, or it is a kind of tyranny without legitimacy. So from this point of view, power is also in the reverse intervention of right. All in all, right and power support and supervise each other, maintaining a delicate balance between freedom and equality.

\section{Conclusion}

In some people's opinion, Habermas's reconstruction of the relationship between right and power is just a simple combination of the related ideas of liberalism and republicanism. It is undeniable that Habermas often shows some neutral temperament in his ideological construction. However, we can not arbitrarily judge that his thought on the relationship between right and power is just the product of simple reconciliation and compromise.

In fact, compared with the traditional concept, Habermas's thought on the relationship between right and power has two prominent values:

Firstly, the argument angle of Habermas's thought is holistic. No matter liberals or republicans, they all base their argument on a certain side when they construct the relationship between right and power. However, in Habermas's opinion, right and power have no primary or secondary distinction, so he always insists on analyzing the relationship between them from the overall dimension of social democratic politics, and makes a more comprehensive and objective judgment.

Secondly, the thinking mode of Habermas's thought is dialectical. On the whole, Habermas abandoned the conventional one-dimensional linear thinking mode of traditional political philosophy. On the basis of the principle of discourse, he got through the internal relationship between right and power and successfully realized the bidirectional argumentation of the isomorphic relationship of mutual restriction and interdependence between them, which effectively promoted the further development of political philosophy.

To sum up, Habermas's cognition of the relationship between right and power is relatively radical in theoretical attitude, and reflects a strong spirit of innovation. More importantly, the thought includes the social communication field neglected by the current representative democracy model, and successfully realizes the benign interaction between the social communication field and the political field, which is undoubtedly of great significance for maintaining the legitimacy of political power and enhancing social solidarity.

\section{References}

[1] Hong Xia. Habermas's Discourse Democracy and the Reconstruction of Western Legal System [J]. Journal of Guangxi University (Philosophy and Social Sciences), 2020 (2): 55 .

[2] Jürgen Habermas. Faktzitt und Geltung [M]. Translated by Shijun Tong. Beijing: Life, Reading and Xinzhi Sanlian Bookstore, 2003.

[3] Xiaosheng Wang. Republicanism and Liberalism -- On Habermas's Concept of Deliberative Democracy [J]. Philosophical investigations, 2008 (1): 14.

[4] Silin Ai, Guixian Wang, Chao Ma. Democracy, Justice and Globalization -- A Study of Habermas's Political Philosophy [M]. Beijing: Peking University Press, 2010. p. 64.

[5] Hong Yan. From Communicative Community to Legal Community: Habermas's Evolutionary Reconstruction of Modern Western Countries [J]. Journal of Huazhong University of Science and Technology (Social Sciences), 2019 (3): 60 .

[6] Shitian Luo. Rational Reconstruction and Rational Dilemma in Modern State Governance [J]. Social Sciences in GuangXi, 2019 (7): 104.

[7] Hongjun Gao. The Discourse Theory of Law and Democratic Legitimate State [M]. Beijing: Tsinghua University Press, 2007. p. 95.

[8] Renzhong Yang. Public Domain Theory [M]. Beijing: People's Publishing House, 2009. p. 143.

[9] Wei Chen. Arendt and the Restoration of Politics [M]. Beijing: Law Publishing House, 2008. p. 92.

[10] Hannah Arendt. Human Condition [M]. Translated by Yinli Wang. Shanghai: Shanghai People's Publishing House, 2009, p. 190.

[11] Hao Dong. Habermas and the Exploration of the Public Domain and Its Effects: Written on the 90th Anniversary of Habermas [J]. Yuejiang Academic Journal, 2019 (6): 93.

[12] Jean-Jacques Rousseau. Social Contract [M]. Translated by Zhaowu He. Beijing: The Commercial Press, 2003. p. 35.

[13] Mingan Kong, Yong Tan. Subject of Communication and Subject of Generation: A Comparative Study of Habermas's and Zizek's Intersubjectivity Thoughts [J]. Journal of Anhui Normal University (Hum. \& Soc. Sci.), 2020 (3): 51.

[14] Gang Liu. Habermas and the Fundamentals of Modern Philosophy [M]. Beijing: People's Publishing House, 2008. p. 346.

[15] Xiaosong Zheng. Technology and Rationalization: A Study of Habermas's Technology Philosophy [M]. Jinan: Qilu Publishing House, 2007. p. 101. 